УДК 357

DOI: https://doi.org/10.26642/jen-2021-2(96)-9-14

\author{
О.Й. Юрківський, к.е.н., доц. \\ С.В. Свірко, д.е.н., проф. \\ Т.П. Назаренко, к.е.н., доц. \\ Державний університет «Житомирська політехніка»
}

\title{
Соціальні збори як інституційна основа податкової довіри в податковій системі
}

Формування соиіально орієнтованої економіки залежить від багатьох факторів, зокрема, від структури й видів загальнодержавних і місчевих податків. Серед податків та зборів, щчо визначенні Податковим кодексом, особливе місие займає єдиний соиіальний внесок або збір, надходження якого залежить від рівня довіри між державою, роботодавием і працівником. Головною метою застосування подібних зборів є забезпечення сочіальних стандартів і різних верств населення сочіальними послугами. Головною перевагою таких зборів є еквівалентність обміну між платниками та фондами через відповідний проміжок часу, врахування особливостей платника податку, щзо потенційно забезпечує максимальний рівень довіри в довгостроковому періодi. Практика застосовування сочіальних зборів показує проблематичність в питанні виконання соиіальних стандартів, а порушення балансу податкового тиску в бік підвищення на роботодавиів призводить до підвищення рівня тіньової економіки. Однією з інституційних причин є створення із врахуванням власних особливостей, віртуальної та антисоиіальної економічної системи, спрямованої на максимізацію дї середньовічного принципу «laissez-faire», превалювання принщипів моделі «Ното Есопотісия», використання переважно ринкових інституцій у всіх сферах поряд з поступовою мінімізацією ролі держави як економічного суб'єкта при значних $i$ деталізованих законодавчо затверджених суспільних стандартах життя. Це суперечить насамперед європейській практиці застосування соціальних внесків, відбувається втрата довіри та часу, щьо в результаті посилює відтік населення з краӥни як платників податків і споживачів благ.

Ключові слова: податки, соціальні збори, податкова довіри.

Актуальність теми. Сфера податкових відносин залишається в центрі уваги урядів України останніх років, а прийняті податкові зміни торкнулися як кількості податків так і їх адміністрування, що позитивно вплинуло на податкові рейтинги країни в 2014-2021 рр. Зменшення кількості обов'язкових платежів, зміна ставки єдиного соціального внеску знизили податковий тягар на суб'єктів господарювання практично усіх сфер, трансформувалися ставки й критерії застосування єдиного податку в 2020 рр. Електронне ж подання звітності та цифровізація податкової сфери зменшили витрати часу як підприємців, так і бухгалтерів під час обрахунку обов'язкових платежів і складання податкової звітності. Однак зменшення ставок єдиного соціального внеску на тлі військових дій, падіння ВВП та поширення COVID-19 сформували додаткове навантаження на фонди соціального страхування, суттєво загострили вже традиційну для національних соціально-економічних відносин проблему збитковості фондів та встановлення еквівалентності податкової довіри у відносинах між такими суб'єктами, як: держава, роботодавці, працівники, профспілки. Відтак проблеми розширення бази оподаткування, зменшення тіньового сектору економіки загалом i заробітних плат зокрема, застосування формальних та неформальних інституцій продовжують бути об'єктами досліджень широкого кола вчених: С.В. Бреус, С.А. Гальчинського, М.Я. Демяненка, М.П. Денисенко, В.А. Предборського, Т.Т. Ковальчука, В.М. Пинзеника та інших.

Викладення основного матеріалу. Армія, освіта й медицина для кожної країни формують базис майбутньої безпеки, незалежності, суверенності та, відповідно, вимагають оптимального фінансування і зазвичай знаходять законодавче закріплення у відповідних статтях законодавчо-нормативних актів та Конституції України. Через бюджетно-податкову політику здійснюється вплив на формування доходів держави, фінансування відповідних конституційних статей, а обов'язкові податкові платежі переважно $є$ чи не єдиними дієвим інструментом забезпечення фінансовими ресурсами бюджетів та різних фондів.

Податки традиційно сприймаються платниками як інструмент несправедливості, вважаються антиринковими, здійснюється апелювання до класичного принципу «laissez-faire» («принцип невтручання»), однак в межах окремих економічних моделей за останні століття були знайдені різні підходи до формування балансу між ринковими силами та суспільними або соціальними потребами. Досвід країн Свропи відображає багатоваріантність в питанні знаходження балансу між цими соціальноекономічними явищами, а уряди по різному вирішують складні проблеми одночасного узгодження таких економічних завдань, як:

1) посилення фінансування соціально значимих сфер; 
2) зниження рівня тіньової економіки та підвищення податкової довіри, мотивації сплачувати податки й збори;

3) покращення іміджу держави в податковій сфері для залучення іноземних інвестиційних ресурсів.

Протягом 30-го періоду реформування національної податкової системи використовувався широкий спектр фіскальних експериментів, які мали різні наслідки для виконання основних функцій податків та торкалися зміни:

- філософії оподаткування;

- елементів правового механізму та правил адміністрування;

- підходів до податкового контролю.

Розглядаючи податкову систему України у взаємодії із соціальним страхуванням через призму інституціоналізму, як традиційного, так i сучасного, доцільно виокремити дію формальних та неформальних інституцій, які на основі відповідних вже формалізованих принципів оподаткування та елементів правового механізму забезпечують надходження до фондів соціального страхування, виконують насамперед суспільні функції і опосередковано державні, маючи відносний примусовий характер [6]. Податкові експерименти, постійна зміна логіки оподаткування в соціальних зборах, визначення «спрощеної» та «загальної» систем оподаткування після 1998 р. були спрямовані на створення й удосконалення саме формальних інституцій і частково неформальних, але соціальна та суспільна складові використання і базис таких обов'язкових платежів залишалися поза увагою й пов’язані головним чином з такими неформальними інституціями:

- потаткова довіра;

- правила взаємодії держави та платників юридичних і фізичних осіб;

- мотивація сплачувати податки й особливо збори соціального характеру.

Застосування зборів як виду обов'язкового платежу здійснювалося у різних формах - соціальних зборів, гербового збору, збору з власників собак, інноваційного збору та збору з гастрольних заходів передбачало насамперед фіскальне спрямування податкових надходжень до бюджетів відповідних рівнів через оподаткування як традиційних об'єктів, зокрема заробітної плати так і нових, які не охоплювалися вже традиційними податками та зборами в межах Податкового кодексу, а також загальної і спрощеної систем оподаткування [1]. Обидві системи оподаткування, а особливо система єдиного податку, пов'язані насамперед з проблемністю нарахування та сплатою соціальних зборів, зокрема до Пенсійного фонду, як для роботодавця, так і працівника. Застосування подібних зборів у Європі $є$ звичайною практикою, натомість досвід використання в Україні $є$ радше негативним внаслідок фіскальної та соціальної неефективності, хоча саме збори мають забезпечити переваги перед податками з огляду на їх:

- цільову направленість;

- точковість в оподаткуванні окремого об’єкта у різних суб'єктів господарювання;

- забезпечення еквівалентного обміну між державою та платниками.

Якщо податки традиційно ототожнюються 3 тягарем, то збір як обов'язковий податковий платіж передбачає певну еквівалентність в обміні платежу на особисту економічну або соціальну вигоду для платника в майбутньому. Збори соціального характеру кінця ХІХ ст. стали відповідним закономірним результатом продовження розвитку виробничих відносин як податкової, так і страхової справи 3 метою забезпечення виконання певних соціальних стандартів через відносно еквівалентний обмін та систему взаємовідносин між фондами (зокрема державними), профспілками й платниками (роботодавцями й працівниками). Як і звичайні податки, соціальні збори передбачають насамперед податкову довіру та мотивацію сплачувати подібні платежі як працівниками, так і роботодавцями, що формуються протягом тривалого періоду. Практика застосування за часів незалежності є досить незадовільною, а проблеми, закладені ще в часи соціалізації Радянського Союзу, пов'язані 3 використанням командноадміністративної системи. Становлення сучасного соціального оподаткування працівників та роботодавців в Україні нового часу доцільно характеризувати в розрізі таких етапів:

1) перший етап: 1990-1998 pр. - прийняття базових основних актів між державою та профспілками:

- «Положення про фонд соціального страхування Української РСР», узгоджений Радою Міністрів УРСР і Радою Федерації незалежних профспілок України № 25 від 1990 р.;

- Постанова КМУ № 972 від 1998 р. «Про організаційні питання діяльності Фонду соціального страхування України»;

2) другий етап: 1999-2001 pp. - удосконалення законодавства та їх узгодження з профспілками і прийняття законів відносно основних соціальних зборів:

- $\quad$ ЗУ «Про загальнообов'язкове державне соціальне страхування від нещасного випадку на виробництві та професійного захворювання, які спричинили втрату працездатності» (1999р.);

- $\quad$ ЗУ «Про загальнообов’язкове державне соціальне страхування на випадок безробіття» (2000р.);

- $\quad$ ЗУ «Про загальнообов'язкове державне соціальне страхування у зв'язку з тимчасовою втратою працездатності та витратами, зумовленими народженням та похованням» (2001 р.);

3) третій етап: з 2014 р. - початок створення єдиного Фонду соціального страхування України. 
Наведені етапи формування системи соціальних обов'язкових платежів відображають основні тенденції розвитку соціального оподаткування та важливість узгодження різних позицій для формування такої неформальної інституції, як довіра:

- відносно держави як економічного суб'єкта;

- відносно уповноважених профспілкових організацій та наглядових (громадських) рад при єдиному фонді соціального страхування;

- серед найманих працівників;

- відносно роботодавців.

Держава як економічний суб’єкт регулювання соціально-економічних процесів поступово самоусувається від вирішення соціальних питань, а безпосередньо фонд соціального страхування набуває ознак виключно суспільного з підпорядкуванням громадському сектору, профспілкам тощо. Запроваджуючи з 1990 р. обов'язкове соціальне страхування на основі досить значних ставок (близько $40 \%$ в різні періоди часу) та постійно змінюючи правила виходу на пенсію, держава перетворила соціальні внески в елемент фіскальної напруги між такими суб'єктами, як працівники та роботодавці. Це призвело згодом до вимушеного запровадження у 1999 р. спрощеної системи оподаткування, базовою особливістю якої була несплата внесків до фондів насамперед до пенсійного.

Найбільш радикальна зміна підходів до соціальних зборів відбувалася вже після 2014 р. і призвела до деяких позитивів, але нова політика водночас штучно зіштовхнула мотивації роботодавців та працівників в питанні солідарності сплати вже єдиного соціального внеску. Прийняття Закону України «Про збір та облік єдиного внеску на загальнообов’ язкове державне соціальне страхування» від 08.07.2010 р. № 2464, згідно з яким визначено базові засади забезпечення збору та обліку єдиного внеску на загальнообов'язкове державне соціальне страхування, умови та порядок його нарахування і сплати до бюджету, призвело до заміни основних соціальних зборів та появи і сплати єдиного соціального внеску за ставкою 22 \% виключно роботодавцем, що викликало дискусії серед науковців та бізнесу [2].

3 огляду на застосування європейської практики регулювання окремих процесів (сплата внесків роботодавцями та працівниками), національна викликала дискусії серед науковців і практиків, адже порівняно з країнами СС в Україні працівник взагалі не сплачує базових соціальних внесків, а виключно роботодавець (табл. 1). В більшості країн Свропи сформовано відносний паритет у зборах від фонду оплати праці між роботодавцем та працівником. Формат національної сплати ЄСВ спонукає вже до появи змови проти державної політики на основі взаємної вигоди, певного альянсу як працівника, так i роботодавця щодо мінімізації сплати єдиного соціального внеску, що додатково впливає на приховування заробітної плати і збільшує дефіцит соціальних фондів [7, с. 339].

Неоднозначне ставлення працівників та роботодавців й до такої інституції, як профспілки, що поряд 3 непрозорістю акумуляції та використання коштів з фондів, також ускладнює процес формування мотивації та довіри у сфері обов'язкових соціальних зборів. Відбувається часткове повернення в часи Адама Сміта, дикого капіталізму, за якого працівник та роботодавець функціонує «тет-а-тет» у вирішенні більшості проблемних ситуацій, зокрема фінансових, кожен працівник самостійно накопичує суми коштів на майбутню старість та на поточне лікування.

Сучасні профспілкові організації, 3 часів зародження в Європі кінця XIX ст., $є$ основною формальною інституцією та елементом інформаційного ланцюжка між працівниками, з одного боку, та державою з роботодавцями, з другого, в узгодженні багатьох питань соціально-економічного характеру. Значимість профспілок як інституції в межах економічних моделей економік країн світу є різною, від суто декларативного статусу (США) до суттєвого впливу на соціально-економічну політику (Південна Корея, Франція, Японія). В Україні, не зважаючи на створення Федерації професійних спілок України, реальне охоплення працівників профспілками $є$ незначним, проте існують громадські організації (неурядові), які теоретично та практично готові відстоювати певні права перед державою та роботодавцями, мають значно вищий рівень довіри порівняно 3 іншими суб'єктами згідно 3 дослідженнями Центру Разумкова [7]. Складність взаємодії цих двох суб'єктів та держави посилюється також фактом продовженням формування національної моделі «Ното Economicus» («Людина економічна») (рис. 1), відповідним відстороненням значної частини суспільства й бізнесу від вирішення суспільної проблематики, дію правила «сам за себе» 3 максимальною раціональністю в прийнятті рішень.

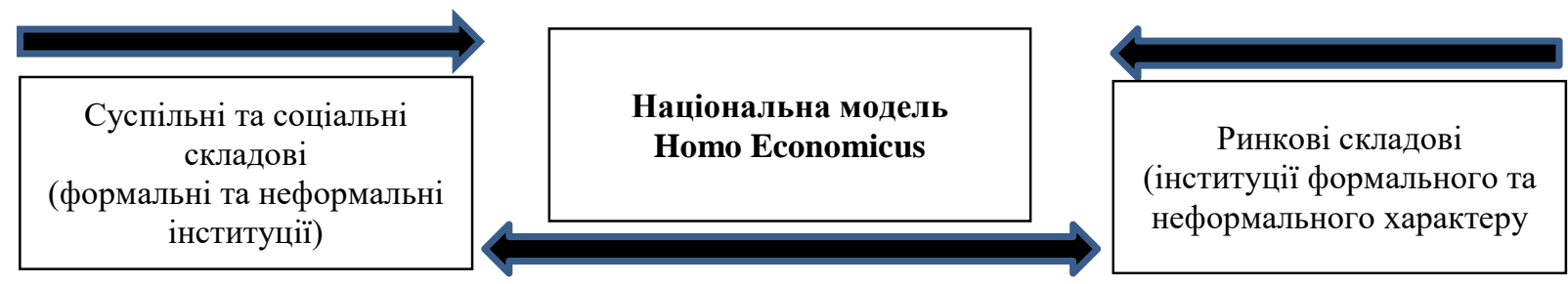

Рис. 1 Складові впливу на націіональну модель «Ното Econотісиз» 
Податки на фонд оплати праціі з працівників та роботодавичів у Європі у відсотках до загального оподаткування 2009-2019 рр. [9]

\begin{tabular}{|c|c|c|c|c|c|c|c|c|c|c|c|c|c|c|c|c|c|c|c|c|c|}
\hline & 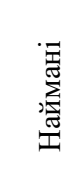 & 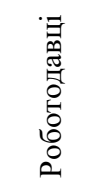 & 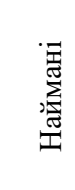 & $\begin{array}{l}\text { : } \\
0 \\
\mathbb{0} \\
0 \\
0 \\
0 \\
0 \\
0 \\
0 \\
0\end{array}$ & 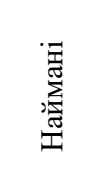 & 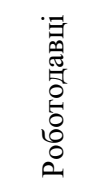 & 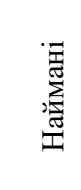 & 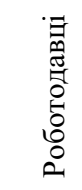 & $\begin{array}{l}\text { 志 } \\
\text { 离 } \\
\text { 壱 }\end{array}$ & 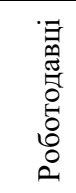 & 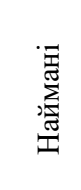 & 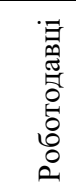 & 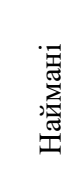 & 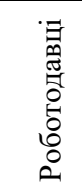 & 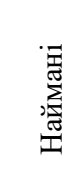 & 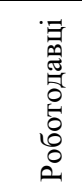 & 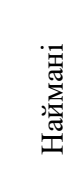 & 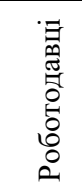 & $\begin{array}{l}\bar{\Xi} \\
\sum_{\mathbb{J}}^{\mathbb{J}} \\
\text { J }\end{array}$ & 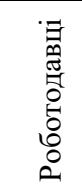 & $\begin{array}{l}\text { 志 } \\
\text { 壳 } \\
\text { 墨 }\end{array}$ \\
\hline & 2009 & 2010 & 2010 & 2011 & 2011 & 2012 & 2012 & 2013 & 2013 & 2014 & 2014 & 2015 & 2015 & 2016 & 2016 & 2017 & 2017 & 2018 & 2018 & 2019 & 2019 \\
\hline Belgium & 30,8 & 19,5 & 30,5 & 19,5 & 30,4 & 19,4 & 29,7 & 19,2 & 29,5 & 19,1 & 29,2 & 19,3 & 28,7 & 18,5 & 28,0 & 18,1 & 27,7 & 17,7 & 27,5 & 18,2 & 27,5 \\
\hline Bulgaria & 7,4 & 16,4 & 16,4 & 17,1 & 16,2 & 15,1 & 17,3 & 15,9 & 16,8 & 16,7 & 18,2 & 16,2 & 17,5 & 16,1 & 17,8 & 17,1 & 18,3 & 17,6 & 18,7 & 17,8 & 19,0 \\
\hline Czecl & 9,8 & 28,0 & 19,8 & 27,4 & 19,8 & 27,1 & 19,8 & 26,8 & 19,8 & 27,0 & 20,4 & 26,6 & 19,7 & 26,7 & 20,3 & 27,0 & 20,7 & 27,6 & 21,6 & 27,8 & 22,0 \\
\hline Denmark & 40,6 & 1,2 & 38,4 & 1,4 & 38,1 & 1,4 & 37,5 & 1,5 & 36,4 & 1,4 & 33,8 & 1,4 & 36,8 & 1,5 & 37,8 & 1,4 & 37,8 & 1,6 & 38,9 & 1,5 & 37,3 \\
\hline Germany & 32,3 & 17,3 & 31,7 & 16,9 & 31,5 & 16,8 & 32,0 & 16,8 & 32,5 & 16,9 & 32,6 & 16,8 & 32,4 & 16,7 & 32,6 & 16,7 & 33,0 & 16,7 & 33,3 & 17,1 & 33,5 \\
\hline Estonia & 15,4 & 35,6 & 16,0 & 34,1 & 16,4 & 32,5 & 16,9 & 32,6 & 17,0 & 31,8 & 17,3 & 31,7 & 16,5 & 31,8 & 16,6 & 32,5 & 16,7 & 33,2 & 15,6 & 33,3 & 15,4 \\
\hline Ireland & 31,8 & 11,3 & 32,2 & 11,7 & 33,9 & 10,5 & 34,8 & 10,8 & 33,6 & 10,9 & 32,8 & 10,7 & 31,3 & 11,0 & 31,5 & 11,2 & 31,3 & 11,3 & 30,9 & 11,8 & 31,2 \\
\hline Greece & 4,9 & 15,8 & 24,1 & 14,3 & 23,4 & 13,5 & 25,9 & 13,1 & 24,1 & 12,4 & 23,6 & 12,0 & 24,1 & 11,4 & 24,0 & 12,3 & 24,8 & 13,3 & 23,8 & 14,1 & 23,8 \\
\hline Spain & 2,3 & 26,7 & 22,0 & 26,6 & 22,6 & 25,0 & 21,9 & 24,3 & 20,9 & 24,2 & 20,8 & 24,1 & 19,8 & 24,5 & 19,8 & 24,7 & 19,9 & 24,7 & 19,8 & 25,9 & 20,5 \\
\hline France & 9,8 & 29,9 & 18,7 & 29,6 & 18,6 & 29,3 & 19,2 & 29,2 & 19,3 & 29,3 & 19,3 & 28,9 & 19,3 & 28,8 & 19,4 & 28,4 & 19,3 & 28,4 & 19,3 & 27,3 & 19,3 \\
\hline Croatia & 4,8 & 17,5 & 24,6 & 17,5 & 23,8 & 16,4 & 23,9 & 15,6 & 23,9 & 16,8 & 23,7 & 16,7 & 21,9 & 15,5 & 21,6 & 15,4 & 20,9 & 15,0 & 21,4 & 14,5 & 21,5 \\
\hline Italy & 0,0 & 25,3 & 20,2 & 25,0 & 19,8 & 23,9 & 19,5 & 23,6 & 19,6 & 23,3 & 19,3 & 22,5 & 19,7 & 22,1 & 19,6 & 22,4 & 19,8 & 23,1 & 19,9 & 23,1 & 19,9 \\
\hline Cyprus & 5,2 & 19,9 & 15,5 & 19,7 & 15,9 & 19,4 & 16,6 & 19,0 & 14,8 & 19,3 & 14,4 & 20,0 & 14,6 & 20,0 & 14,7 & 20,4 & 14,4 & 20,5 & 14,6 & 23,4 & 15,7 \\
\hline Latvia & 27,4 & 22,7 & 27,1 & 21,5 & 26,2 & 20,9 & 26,0 & 20,9 & 25,1 & 19,7 & 25,6 & 19,6 & 25,1 & 19,6 & 24,3 & 19,3 & 25,4 & 20,6 & 24,9 & 21,7 & 26,1 \\
\hline Luxemb & 6,7 & 12,5 & 26,6 & 12,5 & 27,1 & 12,4 & 27,2 & 12,0 & 28,3 & 11,8 & 28,0 & 12,4 & 29,5 & 12,0 & 29,0 & 12,0 & 28,5 & 11,4 & 28,0 & 11,4 & 28,5 \\
\hline Hung & 23,1 & 21,6 & 24,3 & 22,3 & 23,9 & 22,2 & 24,2 & 21,9 & 24,3 & 22,0 & 23,8 & 21,8 & 23,6 & 22,5 & 23,6 & 20,2 & 25,5 & 18,8 & 26,6 & 18,2 & 27,1 \\
\hline & & & & & 22,3 & 8,2 & 22,4 & & 22,7 & & 22,1 & 7,9 & 21,8 & 7,8 & 22,5 & 7,6 & 22,7 & 7,8 & 24,2 & 7,7 & 26,2 \\
\hline Neth & & 2 & & 13,4 & 31,1 & 14,3 & 30,8 & 13,7 & 30,3 & . & 27,8 & 13,8 & 28,5 & 13,6 & 27,3 & 13,4 & 26,6 & 13,7 & 26,5 & 13,9 & 25,7 \\
\hline & & & & 4 & & & 27,6 & & & & & 2,1 & 27,8 & 22,9 & 26,8 & 22,6 & 26,8 & 2,4 & 27,1 & 2,4 & 27,2 \\
\hline & & & & & & & & & & & & & 22,4 & 15,5 & 22,5 & 15,5 & 22,6 & 5,2 & 2,6 & 5,3 & 22,8 \\
\hline & & & & & & & & & & & & & & 15,2 & 5 & 5 & 2,1 & 16,1 & 6 & 16,8 & 21,6 \\
\hline & & & & & & 19 & & & & & & & & & & 1 & 4 & 4,5 & 1 & 3,7 & 42,2 \\
\hline &, 7 & 9 & 32 & & & 14 & & 14 & & & & & & & & & 2 & ,1 & 7 & & 3,1 \\
\hline kia & 19,5 & 24,0 & 19,9 & & & 23,1 & 19,8 & 24,2 & 18,7 & 24,2 & & 24,3 & & 24,3 & 19,6 & 5,3 & 19,3 & 5,8 & 19,7 & 6,4 & 19,9 \\
\hline Finland & 26,6 & 21,0 & 25,4 & 20,5 & 25,1 & 20,7 & 25,7 & 20,2 & 25,1 & 19,9 & 25,5 & 19,8 & 25,0 & 19,7 & 24,9 & 18,1 & 24,7 & 17,8 & 24,9 & 17,6 & 25,1 \\
\hline Sweden & 23,6 & 25,9 & 23,0 & 26,8 & 23,6 & 27,5 & 24,2 & 27,3 & 24,2 & 27,2 & 24,1 & 26,8 & 23,7 & 27,0 & 24,0 & 27,2 & 24,2 & 27,5 & 24,3 & 27,7 & 24,1 \\
\hline Iceland & 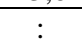 & 12,0 & 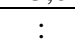 & 11,6 & . & 11,0 & 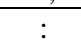 & 11,0 & : & 10,2 & & 10,4 & 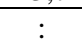 & 7,2 & & 9,7 & & 10,1 & : & 9,8 & 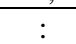 \\
\hline Norway & 5,4 & 13,7 & 4,6 & 13,3 & 45 & 13,6 & 24,8 & 14,5 & 6, & 15,3 & 27,5 & 15,9 & 28,5 & 16,0 & 28,8 & 15,6 & 88,2 & 15,0 & 27,0 & 15,7 & 28,0 \\
\hline $\begin{array}{c}\text { United } \\
\text { Kingdom }\end{array}$ & 28,7 & 11,5 & 28 & 10,7 & 28,1 & 11,1 & 27,1 & 10,9 & 26,7 & 10,9 & 26,3 & 10,9 & 25,9 & 11,1 & 25,8 & 11,5 & 25,7 & 11,6 & 25,7 & 11,7 & 26,1 \\
\hline
\end{tabular}


Недовіра до роботодавців, профспілок, держави з боку працівників підвищується внаслідок низького рівня довіри і серед членів суспільства. Таким чином нівелюються усі переваги збору як обов'язкового податкового платежу:

- максимальна прозорість еквівалентного обміну платників і відповідних фондів;

- чітке встановленням цільового характеру;

- врахування особливостей платника податку (статус, витрати, доходи).

Загалом серед зборів, які застосовуються останнім часом, єдиним, що не викликає сумнівів у необхідності сплати є військовий збір, що пов'язано із значним рівнем довіри до такої інституції, як армія, згідно з соціологічними дослідженнями Центру Разумкова у 2021 р. Військова загроза стала тим основним тригером, який вплинув на підняття довіри до війська, а відповідно й до питання фінансування Збройних сил, зокрема шляхом військового збору. Довіра, наприклад, до лікарів також зросла внаслідок непередбаченої ситуації та боротьби з COVID-19, який став вже драйвером змін у медичній галузі. Однак медичного збору в Україні не існує внаслідок формальної безкоштовності медицини.

Натомість європейський досвід показує обов'язкову наявність подібного внеску поряд 3 традиційними (до пенсійного фонду, фонду зайнятості), проте застосування такого збору $\epsilon$ проблематичним, адже у сфері соціальних зборів з кінця 2020 р. депутатами ВРУ і представниками профспілок пропонується політика об’єднання фондів соціального страхування вже не за назвою, а фактично - з метою економії на постійних витратах у сфері адміністрування. Така політика дійсно може забезпечити певну економію, але фонд стає більш закритим для суспільства, унеможливлюється як мінімум суспільний та контроль роботодавців і працівників за використанням коштів в середині єдиного фонду за різним напрямами соціального забезпечення, й відповідно понижується рівень довіри та мотивація сплати, важливість якої зауважують В.М. Геєць, А.А. Гриценко [3, 4].

Тобто фінансова логіка та фактична необхідність у запровадженні такої формальної інституції, як медичний збір, нівелюються поточною діючою бюджетно-податковою політикою уряду, зокрема у необгрунтованому зниженні податків і зборів для зменшення податкового тиску. А відсутність довіри до ЄСВ та фондів, відсутність прозорості використання коштів і низький рівень довіри загалом нівелюють як медичне страхування, так і збір як вид податкового платежу.

Висновки. Наявні проблеми використання зборів як податкового платежу відображають хаотичність як податкових, так і соціальних реформ, поглиблюють збитковість фондів соціального страхування, а також формують антимотиваційні засади сплати обов'язкових соціальних внесків у довгостроковій перспективі. Втрачається сенс сплати подібних платежів як роботодавцями, так і працівниками, а пенсійна система, фонд виплати «лікарняних» тощо поряд з іншими розглядаються платниками як зайві інституційні інструменти сучасних національних економічних відносин. Результат - втрата податкової довіри до соціальних зборів, неможливість запровадження нового обов'язкового податкового платежу медичного збору - поряд з ССВ, невизначеність відсоткового співвідношення сплати соціальних внесків між працівниками чи роботодавцем.

Фактично в Україні створено з урахуванням власних особливостей, віртуальну та антисоціальну економічну систему, направлену на максимізацію дії середньовічного принципу «laissez-faire», превалювання принципів моделі «Ноmo Economicus», використання ринкових інституцій і відносин у всіх сферах, мінімізацію ролі держави як економічного суб'єкта при значних і деталізованих законодавчо затверджених суспільних стандартах життя та відповідних послуг для різних верств населення. Це суперечить насамперед європейській практиці застосування соціальних внесків, відбувається втрата податкової довіри й часу, що в результаті посилює інші негативні процеси, зокрема відтік населення 3 країни як робочої сили, платників податків та споживачів благ.

\section{Список використаної літератури:}

1. Податковий кодекс України [Електронний ресурс]. - Режим доступу : https://zakon.rada.gov.ua/laws/show/2755.

2. ЗУ «Про збір та облік єдиного внеску на загальнообов'язкове державне соціальне страхування» [Електронний ресурс]. - Режим доступу : https://zakon.rada.gov.ua/laws/show/2464-17.

3. Геєць В.M. Довіра як елемент соціального капіталу в економічному розвитку України / В.M. Геєць // Економічна теорія. - 2010. - № 3. - С. 7-20.

4. Гриценко А.А. Внутрішня структура довіри / А.А. Гриценко // Економічна теорія. - 2010. - № 3. - С. 20-27.

5. Ковальчук T.T. Економічна безпека та політика: $з$ досвіду професійного аналітика / T.T. Ковальчук. - К. : Знання, КОО, 2004. - 638 с.

6. Норт Дуглас Насильство та суспільні порядки. Основні чинники які вплинули на хід історії / Дуглас Норт, Джон Волліс, Баррі Баӥнгес ; пер. Тарас Цимбал. - К. : Наш формат, 2017. - 357 с.

7. Оцінка громадянами ситуації в країні, рівень довіри до соціальних інститутів та політиків, електоральні орієнтації громадян [Електроннй https://razumkov.org.ua/napriamky/sotsiologichni-doslidzhennia/otsinka-gromadianamy-sytuatsii-v-kraini-rivendoviry-do-sotsialnykh-instytutiv-ta-politykiv-elektoralni-oriientatsii-gromadian-zhovten - lystopad-2020r. 
8. Предборський В.А. Детінізація економіки у контексті трансформаційних процесів. Питання теорії та методології : монографія / В.А. Предборський. - К. : Кондор, 2005. - 614 с.

9. Податки в Європі 2020 [Електронний ресурс]. - Режим доступу: https://ec.europa.eu/taxation_customs/sites/taxation/files/taxation_trends_report_2020.pdf.

10. Стратегічні пріоритети детінізації економіки у системі економічної безпеки: макро та мікро вимір : монографія / під ред. О.В. Черевка. - Черкаси : ПП Чабанеко, 2014. - 442 с.

\section{References:}

1. Podatkovyj kodeks Ukrai'ny, [Online], available at: https://zakon.rada.gov.ua/laws/show/2755

2. ZU «Pro zbir ta oblik jedynogo vnesku na zagal'noobov'jazkove derzhavne social'ne strahuvannja», [Online], available at: https://zakon.rada.gov.ua/laws/show/2464-17

3. Gejec', V.M. (2010), «Dovira jak element social'nogo kapitalu v ekonomichnomu rozvytku Ukrai'ny», Ekonomichna teorija, No. 3, pp. 7-20.

4. Grycenko, A.A. (2010), «Vnutrishnja struktura doviry», Ekonomichna teorija, No. 3, pp. 20-27.

5. Koval'chuk, T.T. (2004), Ekonomichna bezpeka ta polityka: $z$ dosvidu profesijnogo analityka, Znannja, KOO, K., $638 \mathrm{p}$.

6. Nort, Duglas, Vollis, Dzhon and Bai'nges, Barri (2017), Nasyl'stvo ta suspil'ni porjadky. Osnovni chynnyky jaki vplynuly na hid istorii', translated by Cymbal, Taras, Nash format, K., 357 p.

7. «Ocinka gromadjanamy sytuacii' v krai'ni, riven' doviry do social'nyh instytutiv ta politykiv, elektoral'ni orijentacii' gromadjan», [Online], available at: https://razumkov.org.ua/napriamky/sotsiologichni-doslidzhennia/otsinkagromadianamy-sytuatsii-v-kraini-riven-doviry-do-sotsialnykh-instytutiv-ta-politykiv-elektoralni-oriientatsiigromadian-zhovten - lystopad-2020r

8. Predbors'kyj, V.A. (2005), Detinizacija ekonomiky u konteksti transformacijnyh procesiv. Pytannja teorii' ta metodologii', monografija, Kondor, K, 614 p.

9. «Podatky v 2020», Jevropi [Online], available at: https://ec.europa.eu/taxation_customs/sites/taxation/files/taxation_trends_report_2020.pdf

10. Cherevko, O.V. (ed.) (2014), Strategichni priorytety detinizacii' ekonomiky u systemi ekonomichnoi' bezpeky: makro ta mikro vymir, monografija, PP Chabaneko, Cherkasy, 442 p.

Юрківський Олександр Йосипович - кандидат економічних наук, доцент, доцент кафедри Цифрової економіки та міжнародних економічних відносин Державного університету «Житомирська політехніка».

https://orcid.org/0000-0003-0297-2519.

Наукові інтереси:

- податки, сучасні економічні теорії, управлінський облік.

Свірко Світлана Володимирівна - доктор економічних наук, професор, професор кафедри Економічної безпеки, публічного управління та адміністрування Державного університету «Житомирська політехніка».

http://orcid.org/0000-0001-9157-4672.

Наукові інтереси:

- облік, аналіз та аудит.

Назаренко Тетяна Петрівна - кандидат економічних наук, доцент, доцент кафедри обліку та аудиту Державного університету «Житомирська політехніка».

http://orcid.org//0000-0001-7702-8122.

Наукові інтереси:

- облік, аналіз та аудит. 